\title{
A brackishwater isolate of Pseudomonas PS-102, a potential antagonistic bacterium against pathogenic vibrios in penaeid and non-penaeid rearing systems
}

\author{
K.K. Vijayan ${ }^{\mathrm{a}}{ }^{*}$, I.S. Bright Singh ${ }^{\mathrm{b}}$, N.S. Jayaprakash ${ }^{\mathrm{b}}$, S.V. Alavandi ${ }^{\mathrm{c}}$, \\ S. Somnath Pai ${ }^{b}$, R. Preetha ${ }^{b}$, J.J.S. Rajan ${ }^{c}$, T.C. Santiago ${ }^{c}$ \\ ${ }^{a}$ Central Marine Fisheries Research Institute (Indian Council of Agricultural Research), Ernakulam North, Cochin-682018, Kerala, India \\ ${ }^{\mathrm{b}}$ Centre for Fish Disease Diagnosis and Management, School of Environmental Studies, Cochin University of Science and Technology, \\ Lake Side Campus, Fine Arts Avenue, Cochin-682016, Kerala, India \\ ${ }^{\mathrm{c}}$ Central Institute of Brackishwater Aquaculture (Indian Council of Agricultural Research) \#75 santhome High Road, Raja Annamali Puram, \\ Chennai 600028, India
}

Received 31 January 2005; received in revised form 22 September 2005; accepted 2 October 2005

\begin{abstract}
A Pseudomonas sp PS-102 recovered from Muttukkadu brackish water lagoon, situated south of Chennai, showed significant activity against a number of shrimp pathogenic vibrios. Out of the 112 isolates of bacterial pathogens comprising Vibrio harveyi, $V$. vulnificus, V. parahaemolyticus, V. alginolyticus, V. fluvialis, and Aeromonas spp, $73 \%$ were inhibited in vitro by the cell-free culture supernatant of Pseudomonas sp PS-102 isolate. The organism produced yellowish fluorescent pigment on King's B medium, hydrolysed starch and protein, and produced $36.4 \%$ siderophore units by CAS assay and $32 \mu \mathrm{M}$ of catechol siderophores as estimated by Arnow's assay. The PS-102 isolate showed wide ranging environmental tolerance with, temperatures from 25 to $40{ }^{\circ} \mathrm{C}$, $\mathrm{pH}$ from 6 to 8 , salinity from 0 to $36 \mathrm{ppt}$, while the antagonistic activity peaked in cultures grown at $30^{\circ} \mathrm{C}, \mathrm{pH} 8.0$ and at $5 \mathrm{ppt}$ saline conditions. The antagonistic activity of the culture supernatant was evident even at $30 \% v / v$ dilution against $V$. harveyi. The preliminary studies on the nature of the antibacterial action indicated that the antagonistic principle as heat stable and resistant to proteolytic, lipolytic and amylolytic enzymes. Pseudomonas sp PS 102 was found to be safe to shrimp when PL-9 stage were challenged at $10^{7} \mathrm{CFU} \mathrm{m}{ }^{-1}$ and by intramuscular injection into of $\sim 5 \mathrm{~g}$ sub-adults shrimp at $10^{5}$ to $10^{8} \mathrm{CFU}$. Further, its safety in a mammalian system, tested by its pathogenicity to mice, was also determined and its $\mathrm{LD}_{50}$ to BALB/c mice was found to be $10^{9} \mathrm{CFU}$. The results of this study indicated that the organism Pseudomonas sp PS 102 could be employed as a potential probiont in shrimp and prawn aquaculture systems for management and control of bacterial infections.
\end{abstract}

(C) 2005 Elsevier B.V. All rights reserved.

Keywords: Pseudomonas; Antagonism; Pathogenic vibrios; Penaeids; Scampi; Probiotic

* Corresponding author. Tel.: +91 484 2394867; fax: +91 484 2394909.

E-mail address: vijayankk@yahoo.com (K.K. Vijayan).

\section{Introduction}

Pathogenic vibrios are involved in significant mortalities in the larviculture and growout phases of crustacean aquaculture (Gomez-Gil et al., 2000). Mass mortality caused by them is a major hindrance in the 
semi-intensive rearing of shrimp in India and other shrimp farming countries (Lightner, 1996; Alavandi et al., 1995; Baticados et al., 1990; Singh, 1990). Species such as Vibrio harveyi, $V$. anguillarum, V. alginolyticus, $V$. parahaemolyticus and $V$. vulnificus have frequently been associated with mortalities both in hatcheries and grow out ponds (Mohney et al., 1994; Baticados et al., 1990; Singh, 1986). In an attempt to control the proliferation of pathogenic vibrios, the prophylactic and therapeutic use of antibiotics has been practiced in commercial hatcheries (Gatesoupe, 1989), creating the more serious problem of antibiotic resistance among the microflora in the environment. (Karunasagar et al., 1994; Amabile-Cuevas et al., 1995; Weston, 1996; Hameed et al., 2003).

The problem of antibiotic resistance and its epidemiological consequences led to the exploration of several alternate approaches for disease management in aquaculture systems. Amongst them the most popular and practical approach is the use of probiotics as prophylactics. The range of probiotics examined for use in aquaculture encompasses both Gram-negative and Grampositive bacteria, bacteriophages, yeasts and unicellular algae (Irianto and Austin, 2002a). Early search for probiotic candidate organisms were based on in vitro antagonism (Verschuere et al., 2000), subsequently the approach of selection based on adhesion, colonization and growth in intestinal mucus has come in (Irianto and Austin, 2002b; Vine et al., 2004). Gram et al. (1999) observed in vitro inhibition of Vibrio anguillarum by Pseudomonas flourescens and obtained lower mortalities in probiotic-treated fish, Oncorhynchus mykiss. Specific inhibition of $V$. harveyi by Pseudomonas aeruginosa has been reported earlier by Torrento and Torres (1996) and Chythanya et al. (2002). In the present study, we report the isolation of a putative probiont, Pseudomonas sp. PS-102, its spectrum of antagonism against vibrios pathogenic to shrimp and prawn, physical conditions for its growth and production of the antimicrobial metabolite, preliminary characterization of the antagonistic principle, and its safety to shrimp and mammalian systems.

\section{Materials and methods}

\subsection{Bacterial isolates}

Pseudomonas sp PS-102 was isolated on ZoBell's Marine Agar 2216 E from the routine water samples collected from the Muttukkadu brackish water lagoon situated about $35 \mathrm{~km}$ south of Chennai. The organism on the primary culture plate was found to inhibit the growth of other bacterial flora on the ZoBell's marine agar plate. This observation prompted us to explore its ability to inhibit shrimp pathogenic vibrios. The colony was purified and identified based on its morphological and physiological characteristics (Krieg and Holt, 1984). The morphological, physiological and biochemical characteristics were similar to the reference strain P. aeruginosa (MTCC 741 (Microbial Type Culture Collection, Chandigarh, India).

One hundred and twelve isolates including 106 isolates of Vibrio spp. and 6 isolates of Aeromonas spp isolated from larval rearing systems of Penaeus monodon and Macrobrachium rosenbergii and infected shrimp and prawn samples over a period of time were used to test the antagonistic potential of Pseudomonas sp PS-102 isolate. They were isolated on ZoBell's Marine Agar $2216 \mathrm{E}$ and identified to genera following Krieg and Holt (1984) and Oliver (1982) and to species following Alsina and Blanch (1994). The cultures were maintained as part of the culture collection at Centre for Fish Disease Diagnosis and Management, Cochin University of Science and Technology.

\subsection{Antagonism assay}

The Pseudomonas PS-102 isolate was inoculated in ZoBell's Marine broth and incubated at $30{ }^{\circ} \mathrm{C}$ for 72 $\mathrm{h}$ on a shaker $(90 \mathrm{rpm})$. The culture was centrifuged at $6000 \times g$ for $10 \mathrm{~min}$ and filtered through a $0.2 \mu \mathrm{m}$ pore size filter (Millipore). Twenty microlitres of this cell free preparation was impregnated on four $\mathrm{mm}$ diameter sterile discs (HiMedia) and air dried. These discs were placed on ZoBell's Marine agar (HiMedia) plates previously swabbed with the target bacterial isolates grown to log phase in ZoBell's marine broth. The plates were then incubated at $30{ }^{\circ} \mathrm{C}$ for $24 \mathrm{~h}$ and the zone of inhibition around the discs was measured and recorded against 112 target organisms.

\subsection{Optimal temperature, $p H$ and salinity for the production of antagonistic action by Pseudomonas PS-102}

The optimal conditions for growth and production of antagonistic principle by Pseudomonas PS-102 was assessed by growing the culture in ZoBell's marine broth at various temperatures $\left(25,30,35\right.$ and $\left.40{ }^{\circ} \mathrm{C}\right)$, $\mathrm{pH}(6.0,6.5,7.0,7.5$ and 8.0) and salinities $(5,10,15$, $20,25,30$ and $35 \mathrm{ppt}$ ) in $100 \mathrm{ml} 1 \%$ peptone water for a period of 7 days in duplicate. Samples for cell count and antagonistic activity were drawn every $24 \mathrm{~h}$. One milliliter of the culture was processed for evaluating the 
antagonistic potential against a virulent strain of $V$. harveyi (LB 3, penaeid system isolate) by the disc diffusion method as explained earlier. The cell counts were determined by serial dilution and the pour plate technique.

\subsection{Effect of dilution of the cell free supernatant of} Pseudomonas PS-102 on the antibacterial activity against $V$. harveyi $L B 3$

The cell free culture supernatant was prepared as described earlier from a culture of Pseudomonas PS102 grown in ZoBell's marine broth under optimal conditions as determined in the previous experiment $\left(30{ }^{\circ} \mathrm{C}, \mathrm{pH} 8.0,0.5 \% \mathrm{NaCl}\right.$ for $72 \mathrm{~h}$ ). Dilutions of the filtrate containing the potential antibacterial compound were prepared up to $10 \%(v / v)$ in sterile phosphate buffered saline (pH 7.4). Antagonistic assay against $V$. harveyi LB3 was tested by the disc diffusion method as described earlier.

\subsection{Preliminary characterization of the antibacterial component in cell free supernatant of Pseudomonas PS-102}

The cell free culture supernatant of Pseudomonas PS-102 containing the antibacterial principle was obtained from the culture grown under optimal conditions as given earlier. It was treated with proteinase $\mathrm{K}$ (1 $\left.\mathrm{mg} / \mathrm{ml}, 3{ }^{\circ} \mathrm{C}\right)$, pronase $\left(2 \mathrm{mg} / \mathrm{ml}, 37^{\circ} \mathrm{C}\right), \alpha$-chymo$\operatorname{trypsin}\left(5 \mathrm{mg} / \mathrm{ml}, 37^{\circ} \mathrm{C}\right)$, trypsin $\left(50 \mathrm{mg} / \mathrm{ml}, 37^{\circ} \mathrm{C}\right)$, lysozyme $\left(1 \mathrm{mg} / \mathrm{ml}, 25^{\circ} \mathrm{C}\right)$, lipase $\left(1 \mathrm{mg} / \mathrm{ml}, 37^{\circ} \mathrm{C}\right)$, and $\alpha$-amylase $\left(1 \mathrm{mg} / \mathrm{ml}, 25^{\circ} \mathrm{C}\right)$. After incubation for 1 $\mathrm{h}$, antibacterial activity against pathogenic $V$. harveyi LB 3 along with appropriate controls was tested by the disc diffusion method.

The heat stability of the antibacterial component was tested by heating the cell free supernatant in a water bath for $30 \mathrm{~min}$ at $60{ }^{\circ} \mathrm{C}, 80^{\circ} \mathrm{C}$, and autoclaving for $15 \mathrm{~min}$ at $121{ }^{\circ} \mathrm{C}$, after which antibacterial activity was tested against $V$. harveyi LB 3 by the disc diffusion method.

\subsection{Siderophore production}

Production of siderophores by the Pseudomonas PS102 isolate was determined using blue agar (chrome azurol S or CAS agar) and by CAS assay solutions in cell-free culture supernatants according to Schwyn and Neilands (1987). For the detection of siderophores by the CAS assay method, the isolate was grown in iron deficient defined medium M9 (Maniatis et al., 1982) for
$24 \mathrm{~h}$ and cell free culture supernatants were obtained by centrifugation of the cultures at $8000 \times g$ at $4{ }^{\circ} \mathrm{C}$ for 15 min, followed by filtration using $0.2 \mu \mathrm{m}$ pore size filters. Five millilitres of cell-free culture supernatant thus prepared and $0.5 \mathrm{ml}$ of CAS assay solution were mixed, and after equilibrium was reached, absorbance of this solution at $630 \mathrm{~nm}$ was recorded using SmartSpec spectrophotometer (BioRad). An un-inoculated medium was used as reference and expressed as \% siderophore units (Payne, 1994). Further, the production of hydroxymate and catechol siderophores was tested by Csaky's assay and Arnow's assay, respectively, using 2,3-dihydroxybenzoic acid as a standard (Payne, 1994).

\subsection{Pathogenicity test}

\subsubsection{Pathogenicity of Pseudomonas PS-102 to P. monodon larvae}

Pathogenicity of Pseudomonas PS-102 isolate was tested on the larvae of P. monodon (stage PL 9) collected from a commercial hatchery. Larvae tested negative for white spot syndrome virus (WSSV) by nested PCR using Kimura's protocols (Kimura et al., 1996) were used. They were maintained for 3 days in $25 \mathrm{ppt}$ seawater and fed with sterile lab made egg custard feed. Fifty PL were distributed in 31 plastic troughs containing 21 sterile seawater. Pseudomonas PS-102 culture grown at $30{ }^{\circ} \mathrm{C}$ on ZoBell's marine agar for 24 $\mathrm{h}$ was scraped from the surface of the plates using a sterile loop and suspended in PBS. The cells were washed twice in PBS and resuspended in sterile PBS to $\mathrm{OD}_{600}$ of 1.0 , corresponding to $5 \times 10^{8} \mathrm{cfu} / \mathrm{ml}$. The shrimp larvae were challenged at $10^{7} \mathrm{cfu} / \mathrm{ml}$. The experiment was carried out in triplicate and the larval mortality was monitored for up to 5 days.

\subsubsection{Pathogenicity of Pseudomonas PS-102 on sub- adult P. monodon}

Sub-adults of $P$. monodon weighing $\sim 5 \mathrm{~g}$ each free from WSSV by nested PCR were acclimatized in 20 ppt seawater for 2 days in the laboratory. The animals were given a stress test using formalin (100 ppm for 1 h) with continuous aeration to eliminate weaker ones. Then they were distributed into groups of 6 animals each in 301 capacity fiberglass tanks containing 20 1 of 20 ppt seawater and maintained at $29-30{ }^{\circ} \mathrm{C}$ for 3 days. Animals were challenged by injecting $0.1 \mathrm{ml}$ $\left(10^{7} \mathrm{cfu}\right)$ of Pseudomonas PS-102 in the region between the telson and last segment of the body using 1 $\mathrm{ml}$ sterile insulin syringes ( $29 \mathrm{G}$; Dispovan). A set of control animals were injected with $0.1 \mathrm{ml}$ sterile PBS. Animals were fed with the commercial pellet feed 
(Higashimaru) and $50 \%$ of the water was exchanged daily. Animals were observed daily during the morning and evening for any sign of weakness and mortality for up to 14 days.

\section{8. $L D_{50}$ of Pseudomonas PS-102 in mice}

Twelve-week-old male BALB/c mice were obtained from the Veterinary College, Thrissur, Kerala. Mice were lightly anesthetized with Halothane (Nicholas Piramal) in a glass desiccator and challenged with $\mathrm{Pseu}$ domonas PS-102 at $10^{9}, 10^{8}, 10^{7}, 10^{6}$ and $10^{5} \mathrm{cfu} / \mathrm{ml}$, with suspensions prepared as mentioned above. Bacterial preparation was administered dropwise through the external nares using a micropipette (Socorex) fitted with fine micropipette tip. The mice were housed in cages (Tarsons) and fed with pellet feed, soaked Bengal gram and water ad libitum. Mice were examined daily and the development of signs of disease and mortality was recorded. The $\mathrm{LD}_{50}$ value was determined following Reed and Muench (1938).

\section{Results}

\subsection{Antagonism assay}

One hundred and twelve bacterial isolates obtained from shrimp and prawn aquaculture systems and diseased tiger shrimp P. monodon and freshwater prawns M. rosenbergii including 106 isolates of Vibrio species and 6 Aeromonas spp. were tested for their susceptibility to the antagonistic component produced by Pseudomonas PS-102. Among the 112 pathogenic bacterial isolates, $73 \%$ (82 isolates) were inhibited by the cellfree culture supernatant of Pseudomonas PS-102, with inhibitory zones ranging from 10 to $25 \mathrm{~mm}$. All the 52 isolates of $V$. harveyi isolated from shrimp affected with luminescent bacterial disease were susceptible to the extracellular product of Pseudomonas PS-102 (Table 1).

3.2. Optimal salinity, $p H$ and temperature for the production of antagonistic action in Pseudomonas PS-102

Although Pseudomonas PS-102 was able to grow from 25 to $40{ }^{\circ} \mathrm{C}$, the optimum temperature for growth recorded for the production of the antagonistic component was $30^{\circ} \mathrm{C}$, with a maximum inhibitory zone of 15 $\mathrm{mm}$ on the 5th day (Fig. $1 \mathrm{a}$ and b). The tested $\mathrm{pH}$ ranges did not result in significant variation in the growth of Pseudomonas PS-102 or inhibitory activity. However, the antagonistic activity was highest at $\mathrm{pH} 8.0$ after 7 days of culture with a clearing zone of $16 \mathrm{~mm}$ (Fig. $1 \mathrm{c}$ and d). Pseudomonas PS-102 showed optimum growth at $5 \mathrm{ppt}$ salinity, wherein, peak growth was attained after the 3rd day (after $60 \mathrm{~h}$ ) with concomitant maximum production of inhibitory metabolite. Antagonistic activity was observed after $48 \mathrm{~h}$ in the broth grown at salinities of 5 and $10 \mathrm{ppt}$ with a clearing zone of $16 \mathrm{~mm}$. Although growth was observed at 30 and 35 ppt the inhibitory activity of the culture supernatants was poor (Fig. 1e and f).

\subsection{Effect of dilution of the cell free supernatant of Pseudomonas PS-102 on antibacterial activity against V. harveyi $L B 3$}

Production of the antagonistic component was observed after about $30 \mathrm{~h}$ of growth when the culture

Table 1

Spectrum of inhibitory activity of extracellular inhibitory principle of Pseudomonas PS-102

\begin{tabular}{llccc}
\hline Pathogen & Source & $\begin{array}{l}\text { No. of isolates } \\
\text { tested }\end{array}$ & $\begin{array}{l}\text { No. of isolates } \\
\text { susceptible }\end{array}$ & $\begin{array}{l}\text { Zone of clearance } \\
\text { (mm) }\end{array}$ \\
\hline Vibrio cholerae & Postlarvae of Macrobrachium rosenbergii & 12 & 5 & $18-22$ \\
Vibrio mediterranei & Postlarvae of Macrobrachium rosenbergii & 7 & 3 & $18-22$ \\
Vibrio vulnificus & Postlarvae of Macrobrachium rosenbergii & 8 & 3 & $18-22$ \\
Vibrio nereis & Postlarvae of Macrobrachium rosenbergii & 11 & 2 & $18-22$ \\
Vibrio parahaemolyticus & Postlarvae of Macrobrachium rosenbergii & 4 & 1 & $18-22$ \\
Vibrio fluviallis & Postlarvae of Macrobrachium rosenbergii & 1 & 2 & 19 \\
Vibrio proteolyticus & Postlarvae of Macrobrachium rosenbergii & 2 & 1 & $18-22$ \\
Vibrio anguillarum & & 1 & 4 & 15 \\
Vibrio alginolyticus & Moribund larvae of Macrobrachium rosenbergii & 8 & 52 & $10-25$ \\
Vibrio harveyii & Moribund postlarvae of Penaeus monodon & 52 & 6 & $15-18$ \\
Aeromonas spp. & Moribund larvae of Macrobrachium rosenbergii & 6 & 112 & 82 \\
Total & & & $15-30$
\end{tabular}


a

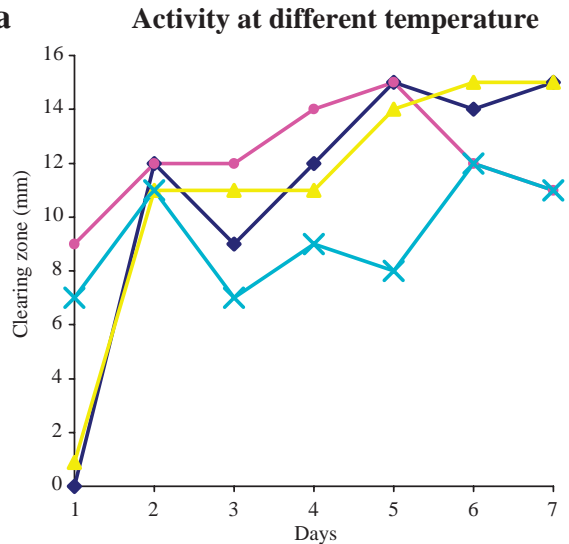

$\longrightarrow 25^{\circ} \mathrm{C} \longrightarrow 30^{\circ} \mathrm{C} \longrightarrow 35^{\circ} \mathrm{C} \longrightarrow 40^{\circ} \mathrm{C}$

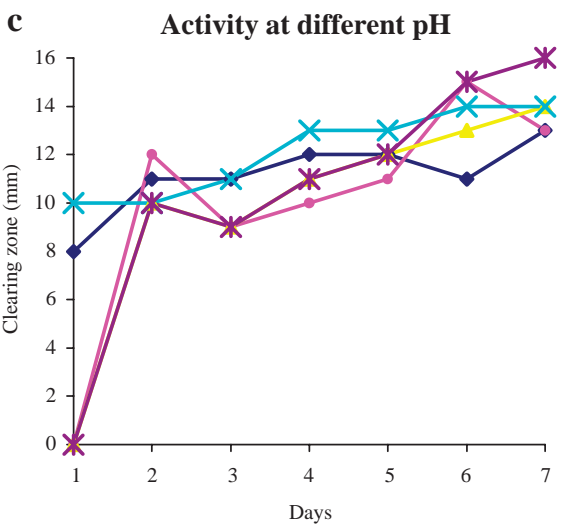

$\longrightarrow \mathrm{pH}-6 \longrightarrow \mathrm{pH}-6.5 \longrightarrow \mathrm{pH}-7 \longrightarrow \mathrm{pH}-7.5 \rightarrow-\mathrm{pH}-8$

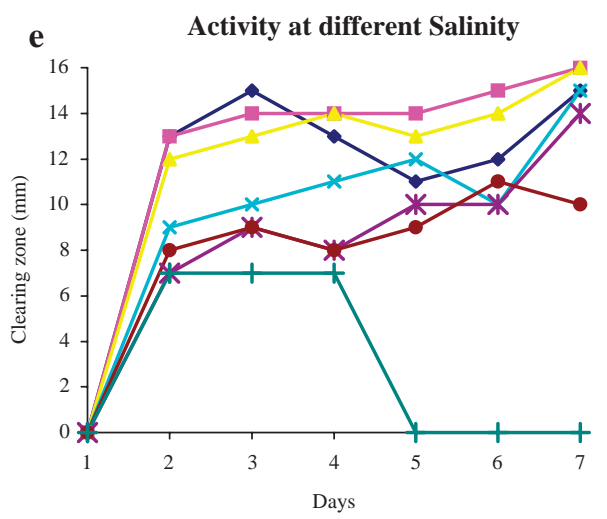

$\longrightarrow 0 \mathrm{ppt} \longrightarrow 5 \mathrm{ppt} \longrightarrow 10 \mathrm{ppt} \multimap 15 \mathrm{ppt}$
$\longrightarrow-20 \mathrm{ppt} \longrightarrow 25 \mathrm{ppt} \longrightarrow 30 \mathrm{ppt}$ b

Growth at different temperature

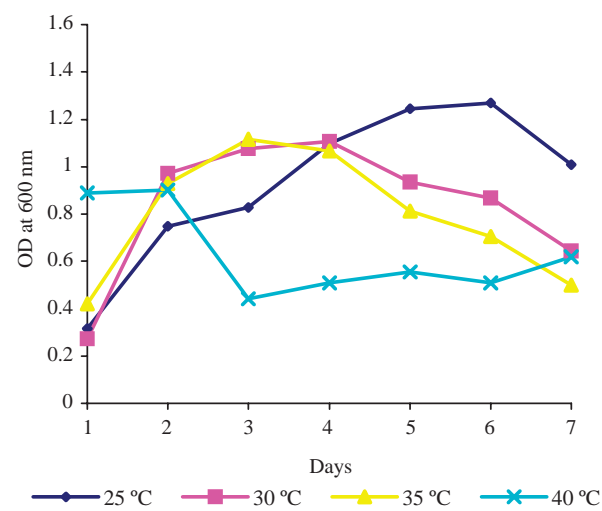

d

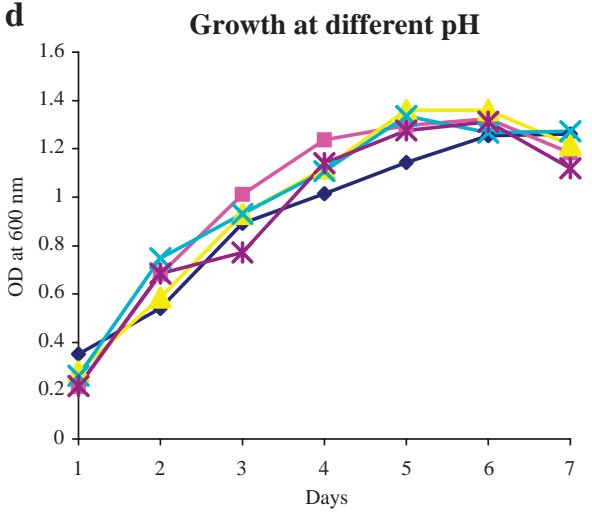

$\longrightarrow$ pH-6 $\longrightarrow$ pH-6.5 $\longrightarrow$ pH-7 $\nsim-\mathrm{pH}-7.5 \longrightarrow{ }_{\mathrm{pH}-8}$

f Growth at different salinity

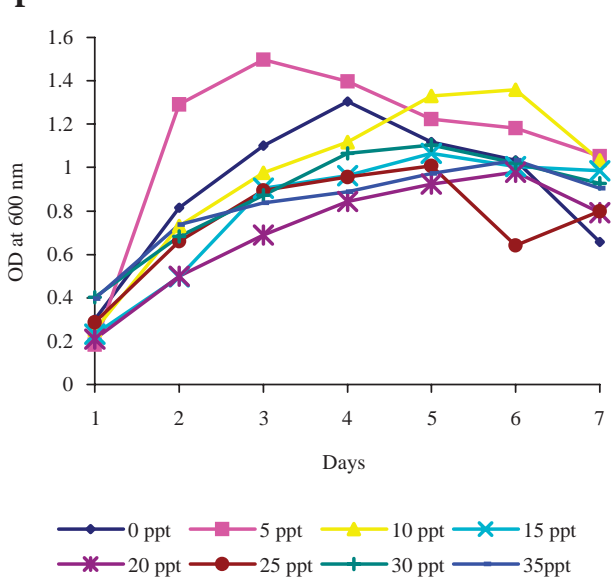

Fig. 1. Effect of salinity, $\mathrm{pH}$ and temperature for the production of antagonistic principle in Pseudomonas PS-102.

entered the late log phase, and the activity peaked in the stationary phase and remained stable thereafter, with only minor fluctuations in the activity (Fig. 2). The cell free supernatant of Pseudomonas PS-102 showed inhibitory activity against the pathogenic luminescent bacterium, $V$. harveyi (LB 3) even after dilution up to $30 \%$ of its original crude concentration (Table 2). 


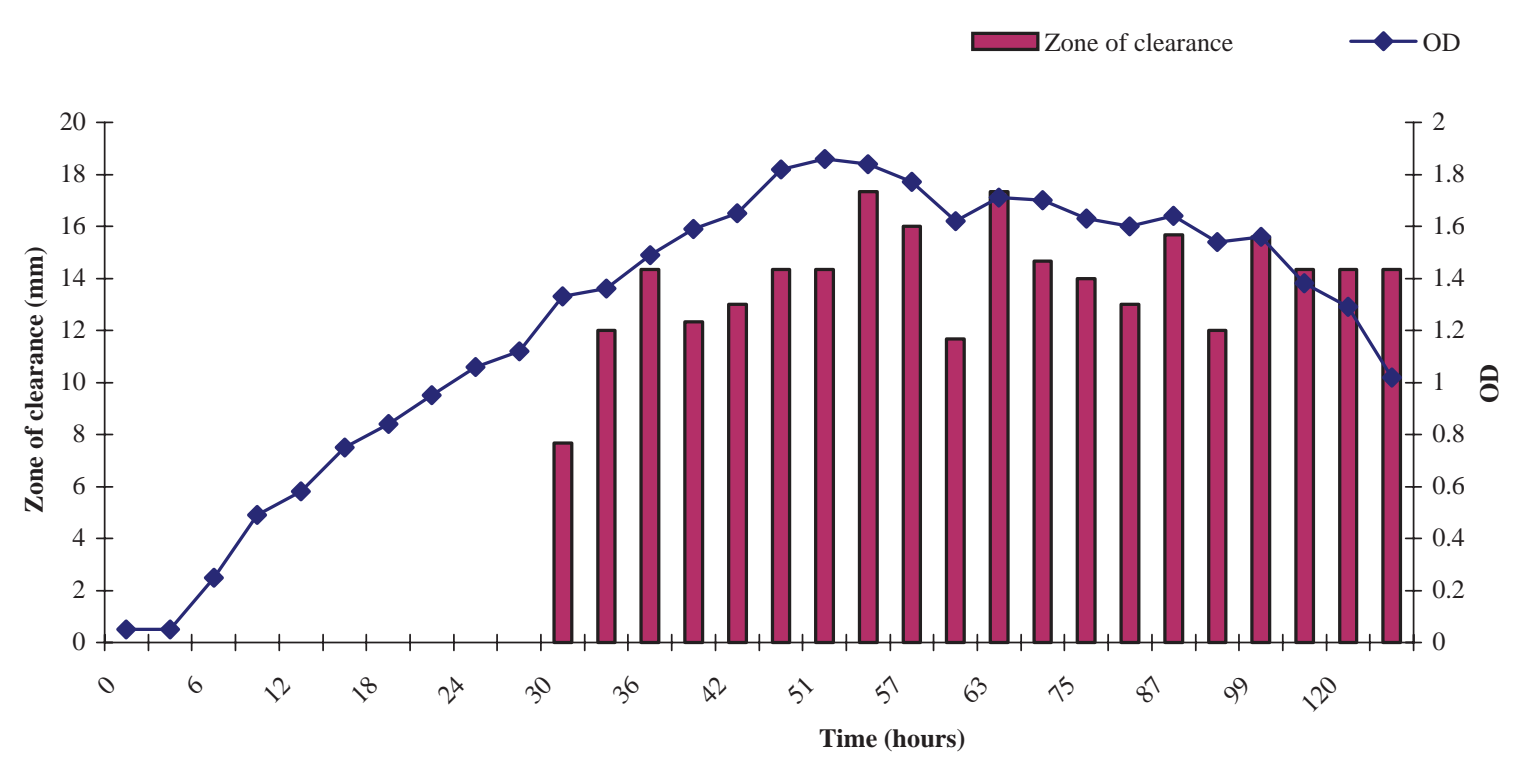

Fig. 2. Production of antagonistic component by Pseudomonas PS-102.

\subsection{Preliminary characterization of antagonistic component}

The antibacterial activity of the cell free supernatant was not affected after treatment with any of the enzymes tested. The zone of inhibition $(12 \mathrm{~mm})$ observed after treatment with the enzymes was equal to the untreated cell free supernatant that served as a control. The antibacterial component did not completely loose its activity even after the crude extract was autoclaved for $15 \mathrm{~min}$ at $121{ }^{\circ} \mathrm{C}$. The zone of inhibition produced by heat-treated culture supernatant decreased to $9 \mathrm{~mm}$, compared to the control $(12 \mathrm{~mm})$.

Table 2

Inhibitory activity of diluted culture supernatant of Pseudomonas PS102 against Vibrio harveyi LB 3

\begin{tabular}{ll}
\hline $\begin{array}{l}\text { Concentration of } \\
\text { the supernatant }\end{array}$ & $\begin{array}{l}\text { Zone of clearance } \\
(\mathrm{mm})\end{array}$ \\
\hline 100 & 15 \\
90 & 12 \\
80 & 10 \\
70 & 11 \\
60 & 10 \\
50 & 7 \\
40 & 6 \\
30 & 6 \\
20 & 0 \\
10 & 0 \\
Control & 0 \\
\hline
\end{tabular}

\subsection{Siderophore production by Pseudomonas PS-102}

Pseudomonas PS-102 produced siderophores on CAS agar as indicated by a yellowish halo around the colonies, indicating their ability to survive and grow in the iron deficient conditions. The organism was found to produce $36.4 \%$ siderophore units as detected by the CAS assay technique, and the siderophore belonged to a catechol group as evidenced by production of $32 \mu \mathrm{M}$ of siderophores in the 5-day-old culture supernatant by Arnow's assay.

\subsection{Pathogenicity of Pseudomonas PS-102 to $P$. monodon}

The pathogenicity test on larvae of $P$. monodon revealed that the Pseudomonas PS-102 isolate did not cause any significant mortality after challenge. The larval rearing water showed the presence of the Pseudomonas PS-102 isolate $\left(10^{7} \mathrm{cfu} / \mathrm{ml}\right)$ until day 5 and

Table 3

Pathogenicity of Pseudomonas PS-102 on P. monodon larvae (PL 9) and adults

\begin{tabular}{|c|c|c|c|c|c|c|}
\hline \multirow[t]{2}{*}{$\begin{array}{l}\text { Pseudomonas } \\
\text { PS-102 } \\
\text { cells/ml }\end{array}$} & \multicolumn{3}{|c|}{$\begin{array}{l}\text { No. of larvae } \\
\text { dead/no. tested }\end{array}$} & \multirow{2}{*}{$\begin{array}{l}\text { Pseudomonas } \\
\text { PS-102 } \\
\mathrm{cfu}^{\mathrm{a}} \text { injected }\end{array}$} & \multicolumn{2}{|c|}{$\begin{array}{l}\text { No. of adults } \\
\text { dead/no. } \\
\text { tested }\end{array}$} \\
\hline & $24 \mathrm{~h}$ & $48 \mathrm{~h}$ & $120 \mathrm{~h}$ & & $24 \mathrm{~h}$ & 14 days \\
\hline $10^{7}$ & $2 / 50$ & $5 / 50$ & $7 / 50$ & $10^{7}$ & $0 / 18$ & $2 / 18$ \\
\hline Control & $3 / 50$ & $4 / 50$ & $8 / 50$ & Control & $0 / 18$ & $2 / 18$ \\
\hline
\end{tabular}

a Colony forming units. 
then was subsequently absent. The pathogenicity test on adult $P$. monodon by injection also did not cause any mortality (Table 3 ).

\section{7. $L D_{50}$ of Pseudomonas PS-102 cells in mice}

$\mathrm{LD}_{50}$ of Pseudomonas $\mathrm{PS}-102$ for BALB/c mice was calculated by the Reed and Muench (1938) method after recording the mortality in each dilution. The $\mathrm{LD}_{50}$ value was found to be $10^{9} \mathrm{cfu}$.

\section{Discussion}

The present study reports a promising antagonistic bacterium Pseudomonas PS-102, isolated from a brackish water lagoon, which showed antagonistic property towards a wide range of pathogenic vibrios isolated from penaeid and Macrobarchium larval rearing systems. The production pattern of the antagonistic component in ZoBell's Marine broth showed an increase in the late stationary phase and this was sustained over a week in the supernatant. Growth as well as production of the antagonistic component over a wide range of temperatures, $\mathrm{pH}$ and salinities suggests that the isolate Pseudomonas PS-102 could be a suitable candidate probiotic for both penaeid and non-penaeid systems.

For application of Pseudomonas PS-102 as a probiotic during routine hatchery operations and Vibrio infections, the data on minimum inhibitory concentrations of cell free supernatants containing the antagonistic factor required for inhibiting the growth of vibrios is essential. Our results of the experiment indicate that the cell free supernatant can be diluted to $30 \%$ of its initial concentration to retain its antagonistic activity.

In order to be considered as a probiotic for application in shrimp culture systems, the strain has to be evaluated for safety to the host and its pathogenicity to a mammalian system (Verschuere et al., 2000, Singh et al., 2003). The Pseudomonas PS-102 isolate did not cause any harmful effects to shrimp larvae or sub-adults upon challenge even at a dose of $10^{7}$ cells introduced by injection. The high $\mathrm{LD}_{50}$ to $\mathrm{BALB} / \mathrm{c}$ mice of $10^{9} \mathrm{cfu}$ also indicates its safety for mammalian system.

The cell free supernatant of the Pseudomonas PS102 showed inhibitory activity on different species of Vibrio and also Aeromonas that have been considered as major pathogens in aquaculture systems (Sindermann, 1990). Numerous studies have implicated siderophores as bacteriostatic substances produced by Pseudomonas species (Guerinot, 1994). Pseudomonas PS-102 produced significantly high levels of siderophores from the catechol group. Inhibitory activity of the cell free supernatant of Pseudomonas PS-102 isolate against $V$. harveyi was not affected by proteolytic, lipolytic and amylolytic enzymes. Chythanya et al. (2002) reported that the antibacterial activity of a cell free supernatant of Pseudomonas I-2 isolate was not affected by proteolytic enzymes like pepsin and trypsin. They indicated that the antagonistic action responsible for the inhibition of vibrios is due to pyocyanin, a chloroform soluble substance. The production of siderophore by Pseudomonas PS-102 would be one of the important inhibiting agents of pathogens (Bossier et al., 1988). However, further characterization of the inhibitory factor of Pseudomonas PS-102 is warranted.

Activity of the cell free supernatant of Pseudomonas PS-102 even after treatment at high temperatures suggests the stability of the antagonistic component. Similar observations were also recorded by Chythanya et al. (2002), who reported that the antibacterial activity of a cell free supernatant of Pseudomonas I-2 isolate was not affected at $100{ }^{\circ} \mathrm{C}$. This property of heat stability would be of greater use during the industrial level production of probiotics. The bacterial biomass along with the culture broth containing the antibacterial metabolite can be incorporated during shrimp feed production, which at certain stages of production is exposed to higher temperatures. Considering the higher protein levels reported in the Pseudomonas sp. (Mohammed, 1996), the bacterial biomass of Pseudomonas PS-102 per se would serve as single cell protein as well.

A number of earlier studies have also shown that bacteria produce inhibitory substances that inhibit the bacterial pathogens in aquaculture systems (Austin et al., 1995; Nogami and Maeda, 1992; Rengpipat et al., 1998; Gram et al., 1999). The use of such bacteria to inhibit pathogens by release of antimicrobial substances is now gaining importance in shrimp farming as a better and more effective alternative than administering antibiotics to manage the health of shrimps (Moriarty, 1997; Verschuere et al., 2000).

Members of the genus Pseudomonas are common inhabitants of soil, freshwater and marine environments and are known to produce a wide range of secondary metabolites (Raaijmakers et al., 1997) inhibiting a wide range of pathogenic bacteria. The fluorescent pseudomonads have been used as biocontrol agents in several rhizophere studies where their inhibitory activity has been attributed to a number of factors, such as the production of antibiotics, hydrogen cyanide or ironchelating siderophores (Raaijmakers et al., 1997). Pseudomonas spp. and vibrios are the most common genera associated with crustaceans (Moriarty, 1997) and are common inhabitants of the aquatic environment 
including shrimp culture ponds (Otta et al., 1999). Torrento and Torres (1996) reported the in vitro inhibition of $V$. harveyi by a Pseudomonas species isolated from the aquatic environment. As with their terrestrial counterparts, aquatic pseudomonads are often antagonistic to other microorganisms (Gram, 1993), including fish pathogenic bacteria (Smith and Davey, 1993) and fish pathogenic fungi (Bly et al., 1997). Gram et al. (1999) demonstrated the protection of rainbow trout administered with $P$. fluorescens AH2 when challenged with $V$. anguillarum. Another study by Smith and Davey (1993) demonstrated that bathing Atlantic salmon in a strain of $P$. fluorescens reduced subsequent mortality from stressinduced furunculosis. Chythanya et al. (2002) also reported inhibition of shrimp pathogenic vibrios by an estuarine strain of Pseudomonas, attributed to a low molecular weight, heat stable non-protein antimicrobial substances.

It has been observed that in the beginning of the shrimp larval rearing period the Pseudomonas group dominates and subsequently members of the family Vibrionaceae take over (Singh, 1986, 1990). Therefore, if we could introduce probiotic isolates that could exclude the vibrios from the system in the beginning itself it should be possible to improve larval survival. The recent advancements in hatchery technology provide every possibility to transform the hatchery system into a closed re-circulating type where the probiotic organisms introduced could be retained within the culture systems without being washed away. The unique characteristics of Pseudomonas sp. PS-102, such as, a significant antibacterial property towards a wide spectrum of bacterial pathogens, its ability to survive under shrimp larval rearing conditions (over 5 days), and tolerance to a wide range of physico-chemical conditions of shrimp rearing systems, as well as safety to shrimp and mammalian systems, qualifies this strain as an ideal probiotic for use in shrimp and scampi rearing systems.

\section{Acknowledgements}

The authors are thankful to Director, CIBA, Chennai for providing facilities for conducting the study. Authors thank Dr. C.P. Balasubramanian, Senior Scientist, CIBA for providing critical comments and editorial suggestions.

\section{References}

Alavandi, S.V., Vijayan, K.K., Rajendran, K.V., 1995. Shrimp diseases. CIBA Bull. 3, 17.
Alsina, M., Blanch, A.R., 1994. A set of keys for biochemical identification of environmental Vibrio species. J. Appl. Bacteriol. 76, 79-85.

Amabile-Cuevas, C.F., Gardenas-Garcia, M., Ludgar, M., 1995. Antibiotic resistance. Am. Sci. 83, 320-329.

Austin, B., Stuckey, L.F., Robertson, P.A.W., Effendi, I., Griffith, D.R. W., 1995. A probiotic strain of Vibrio alginolyticus effective in reducing diseases caused by Aeromonas salmonicida, Vibrio anguillarum and Vibrio ordalii. J. Fish Dis. 18, 93-96.

Baticados, M.C.L., Cruz-Lacierda, E.R., de la Cruz, M.C., DuremdezFernandez, R.C., Gacutan, R.Q., Lavilla-Pitogo, C.R., Lio-Po, G. D., 1990. Diseases of Penaeid Shrimps in the Philippines. Aquaculture Department, SEAFDEC, Tigbauan, Iloilo, Philippines, p. 46.

Bly, J.E., Quiniou, S.M.A., Lawson, L.A., Clem, L.W., 1997. Inhibition of Saprolegnia pathogenic for fish by Pseudomonas fluorescens. J. Fish Dis. 20, 35-40.

Bossier, P., Höfte, M., Verstraete, W., 1988. Ecological significance of siderophores in soil. Adv. Microb. Ecol. 10, 358-414.

Chythanya, R., Karunasagar, I., Karunasagar, I., 2002. Inhibition of shrimp pathogenic vibrios by a marine Pseudomonas I-2 strain. Aquaculture 208, 1-10.

Gatesoupe, F.J., 1989. The effect of bacterial additives on the production rate and dietary value of rotifers as food for Japanese flounder, Paralichthys olivaceus. Aquaculture 83, 39-44.

Gomez-Gil, B., Roque, A., Turnbull, J.F., 2000. The use and selection of probiotic bacteria for use in the culture of larval aquatic organisms. Aquaculture 191, 259-270.

Gram, L., 1993. Inhibitory effect against pathogenic and spoilage bacteria of Pseudomonas strains isolated from spoiled and fresh fish. Appl. Environ. Microbiol. 59, 2197-2203.

Gram, L., Melchiorsen, J., Spanggaard, B., Huber, I., Nielsen, T.F., 1999. Inhibition of Vibrio anguillarum by Pseudomonas fluorescens AH2, a possible probiotic treatment of fish. Appl. Environ. Microbiol. 65, 969-973.

Guerinot, M.L., 1994. Microbial iron transport. Annu. Rev. Microbiol. $48,743-772$.

Hameed, A.S.S., Rahaman, K.H., Alagan, A., Yoganandhan, K., 2003. Antibiotic resistance in bacteria isolated from hatchery-reared larvae and post-larvae of Macrobrachium rosenbergii. Aquaculture 217, 39-48.

Irianto, A., Austin, B., 2002a. Probiotics in aquaculture. J. Fish Dis. $25,633-642$.

Irianto, A., Austin, B., 2002b. Use of probiotics to control furunculosis in rainbow trout, Oncorhynchus mykiss (Walbaum). J. Fish Dis. 25, 333-342.

Karunasagar, I., Pai, R., Malathi, G.R., Karunasagar, I., 1994. Mass mortality of Penaeus monodon larvae due to antibiotic resistant Vibrio harveyi infection. Aquaculture 128, 203-209.

Kimura, T., Yamano, K., Nakano, H., Momoyama, K., Hiraoka, M., Inouye, K., 1996. Detection of penaeid rodshaped DNA virus (PRDV) by PCR. Fish Pathol. 31, 93-98.

Krieg, N.R., Holt, J.G., 1984. Bergey's Manual of Systematic Bacteriology, vol. 1. Williams and Wilkins, Baltimore, USA, pp. $140-219$.

Lightner, D.V. (Ed.), 1996. A Handbook of Shrimp Pathology and Diagnostic Procedures for Disease of Cultured Penaeid Shrimp. World Aquaculture Society, Baton Rouge, Louisiana.

Maniatis, T., Fritsch, E.F., Sambrook, J., 1982. Molecular cloning. A laboratory manual. Cold Spring Harbour Laboratory. Cold Spring Harbour, New York, p. 545. 
Mohammed, S.K., 1996. Heterotrophic marine bacteria as supplementary feed for larval Penaeus monodon. Naga 19, 23-26.

Mohney, L.L., Lightner, D.V., Bell, T.A., 1994. An epizootic of vibriosis in Ecuadorian pond reared Penaeus vannamei Boone, (Crustacea: Decapoda). J. World Aquacult. Soc. 25 (1), 116-125.

Moriarty, D.J.W., 1997. The role of microorganisms in aquaculture ponds. Aquaculture 151, 333-349.

Nogami, K., Maeda, M., 1992. Bacteria as biocontrol agents for rearing larvae of the crab Portunus trituberculatus. Can. J. Fish. Aquat. Sci. 49, 2373-2376.

Oliver, J.D., 1982. Taxonomic scheme for the identification of marine bacteria. Deep Sea Res. 29, 795-798.

Otta, S.K., Karunasagar, I., Karunasagar, I., 1999. Bacterial flora associated with shrimp culture ponds growing Penaeus monodon. J. Aquat. Trop. 14, 309-318.

Payne, S.M., 1994. Detection, isolation and characterization of siderophores. Methods in Enzymol. 235, 329-357.

Raaijmakers, J.M., Weller, D.M., Thomashow, L.S., 1997. Frequency of antibiotic-producing Pseudomonas spp. in natural environments. Appl. Environ. Microbiol. 63, 881-887.

Reed, L.J., Muench, H., 1938. A simple method of estimating fifty per cent endpoints. Am. J. Hyg. 27, 493-497.

Rengpipat, S., Phianphak, W., Piyatiratitivorakul, S., Menasveta, P., 1998. Effects of a probiotic bacterium on black tiger shrimp Penaeus monodon survival and growth. Aquaculture 167, 301-313.

Schwyn, B., Neilands, J.B., 1987. Universal chemical assay for the detection and determiantion of siderophores. Anal. Biochem. 160, 47-56.

Sindermann, C.J., 1990. 2nd ed. Principal Diseases of Marine Fish and Shellfish, vol. 2. Academic Press, New York. 516 pp.
Singh, I.S.B., 1986. Studies on the Bacteria Associated with Penaeus indicus in a Culture System. $\mathrm{PhD}$ Thesis, Cochin University of Science and Technology, Cochin, Kerala, India.

Singh, I.S.B., 1990. Bacterial flora of larvae and larval rearing system of the giant fresh water prawn Macrobrachium rosenbergii. Proc. 2nd Kerala Science Congress. Trivandrum, India.

Singh, I.S.B., Yadava, Y.S., Pai, S.S., 2003. Aquaculture drug regulations in the Indian context. In: Singh, I.S.B., Pai, S.S., Philip, R., Mohandas, A. (Eds.), Aquaculture Medicine. Cochin University of Science and Technology, Cochin, India, pp. 323-332.

Smith, P., Davey, S., 1993. Evidence for the competitive exclusion of Aeromonas salmonicida from fish with stress-inducible furunculosis by a fluorescent pseudomonad. J. Fish Dis. 16, 521-524.

Torrento, M., Torres, J., 1996. In vitro inhibition of Vibrio harveyi by Pseudomonas sp. isolated from aquatic environment. UPV J. Nat. Sci. 1, 130-138.

Verschuere, L., Rombaut, G., Sorgeloos, P., Verstraete, W., 2000. Probiotic bacteria as biological control agents in aquaculture. Microbiol. Mol. Biol. Rev. 64, 655-671.

Vine, N.G., Leukes, W.D., Kaiser, H., 2004. In vitro growth characteristics of five candidate aquaculture probiotics and two fish pathogens grown in fish intestinal mucus. FEMS Microbiol. Lett. 231, 145-152.

Weston, D.P., 1996. Environmental considerations in the use of antibacterial drugs in aquaculture. In: Michel, C.M., Alderman, D. J. (Eds.), Aquaculture and Water Resource Management. Office International des Epizooties, Paris, pp. 494-509. 